\title{
GMR
}

\section{Mechanism of reversal of multidrug resistance by curcumin in human colorectal cancer cell line HCT-8/5-FU}

\author{
Y.X. Fan ${ }^{1}$, P. Abulimiti ${ }^{1}$, H.L. Zhang ${ }^{1}$, Y.K. Zhou ${ }^{2}$ and L. Zhu ${ }^{2}$ \\ ${ }^{1}$ Second Oncology Department, \\ The Fourth Affiliated Hospital of Xinjiang Medical University, Urumqi, \\ Xinjiang, China \\ ${ }^{2}$ Department of Traditional Chinese medicine, \\ The Hospital of Xinjiang Production and Construction Corps, Urumqi, \\ Xinjiang, China \\ Corresponding author: H.L. Zhang \\ E-mail: huwenting725@163.com \\ Genet. Mol. Res. 16 (2): gmr16029414 \\ Received October 6, 2016 \\ Accepted June 2, 2017 \\ Published June 29, 2017 \\ DOI http://dx.doi.org/10.4238/gmr16029414 \\ Copyright $(2017$ The Authors. This is an open-access article distributed under the terms of \\ the Creative Commons Attribution ShareAlike (CC BY-SA) 4.0 License.
}

\begin{abstract}
Since there are no studies on the reversal of multidrug resistance by curcumin in the human colorectal cancer cell line HCT$8 / 5-\mathrm{FU}$, our aim was to search for highly efficient reversal agents and investigate the underlying mechanisms of this reversal. The cytotoxic effects of curcumin and 5-FU on HCT-8 and HCT-8/5-FU cells and the reversal effects of 5-FU in combination with curcumin on HCT8/5-FU cells were measured using cell counting kit-8. Apoptosis and the cell cycle were analyzed by flow cytometry. Protein and mRNA expression levels of BCL-2, survivin, P-gp, and HSP-27 were detected by western blotting and quantitative real-time reverse transcription polymerase chain reaction, respectively. Curcumin inhibited the growth of HCT- 8 and HCT- $8 / 5$-FU cells. It significantly reduced the $\mathrm{IC}_{50}$ of 5 -FU for HCT-8/5-FU cells $(\mathrm{P}<0.01)$ and the expression of BCL2, survivin, P-gp, and HSP-27 in the cells. Curcumin can effectively
\end{abstract}

Genetics and Molecular Research 16 (2): gmr16029414 
reverse multidrug resistance in human colorectal cancer drug-resistant HCT-8/5-FU cells. The mechanism through which this occurs may be associated with decreased expression of BCL-2, survivin, P-gp, and HSP-27. Curcumin may therefore have clinical implications as a new agent for colorectal cancer.

Key words: Multidrug resistance; Curcumin; Colorectal cancer; Drug-resistant cell line; 5-FU; HCT-8

\section{INTRODUCTION}

Colorectal cancer is one of the most common malignancies of the digestive system. It is a highly malignant cancer with rapid disease progression and is, therefore, a serious threat to human health (Lu et al., 2013). Current clinical therapies for colorectal cancer include surgery, chemotherapy, radiotherapy, and treatment with Chinese medicine, of which chemotherapy is often the only option if the cancer has progressed beyond the possibility of successful treatment with surgery and radiotherapy ( $\mathrm{Li}$ and $\mathrm{Li}, 2015)$. However, the efficacies of various chemotherapy regimens appear to have reached their "plateau", partly due to the development of multidrug resistance (MDR) by colorectal cancer cells (Chang et al., 2006). MDR in tumor cells is a phenomenon in which cells that are resistant to one anti-cancer drug acquire resistance for other anti-cancer drugs having different chemical structures and different targets (Ahmad et al., 2015). MDR is a normal phenomenon under physiological conditions since there are no intended targets or specific reactions when a drug enters normal organs, tissues, or cells. Under pathological conditions, however, interaction between a drug and drug-resistant cells may lead to the loss of sensitivity to multiple drugs, resulting in treatment failure. Research on MDRreversal agents is therefore the key to overcoming the failure of chemotherapy.

There are obvious advantages and great developmental potential in the application of traditional Chinese medicine for MDR reversal. It is imperative to actively search for new single reversal agents in Chinese medicine to enhance treatment efficacy and to improve patients' quality of life. Curcumin is widely found in rhizomes of Zingiberaceae plants, such as Curcuma longa, C. zedoaria, and C. wenyujin. In previous studies, curcumin has demonstrated broad pharmacological activities, including anti-inflammatory, anti-oxidative, and anti-tumor effects (Guzzarlamudi et al., 2016). In addition, it has been found that curcumin can reverse drug resistance in tumor cells from gastric, hepatic, and cervical cancers as well as other malignancies (Colacino et al., 2016; Muddineti et al., 2016). The mechanism by which this reversal occurs remains unclear. In this study, the activity of curcumin was investigated in drug-sensitive and drug-resistant human colorectal cancer cell lines to assess effects on reversal of drug-resistance and to understand the underlying mechanisms.

\section{MATERIAL AND METHODS}

\section{Materials}

Human colorectal cancer cell lines HCT-8 (drug-sensitive) and HCT-8/5-FU (drug-resistant), as well as newborn calf serum, were purchased from Zhejiang Tianhang Biotechnology Co. Ltd. (Huzhou, China). Trypsin, RPMI-1640 complete medium, and

Genetics and Molecular Research 16 (2): gmr16029414 
$0.25 \%$ trypsin solution were purchased from Thermo Fisher Scientific (Waltham, MA, USA). Curcumin and 5-FU standards were purchased from Sigma-Aldrich (St. Louis, MO, USA). Cell counting kit-8 (CCK-8) was purchased from Bestbio Biotechnologies (Shanghai, China).

\section{Cell culture}

HCT- 8 and HCT- $8 / 5$-FU cells were cultured in a humidified incubator at $37^{\circ} \mathrm{C}$ with $5 \% \mathrm{CO}_{2}$ in RPMI-1640 medium supplemented with $10 \%$ newborn calf serum, $160 \mathrm{IU} / \mathrm{L}$ insulin, $100 \mathrm{U} / \mathrm{mL}$ penicillin, and $100 \mu \mathrm{g} / \mathrm{mL}$ streptomycin. Trypsin digestion with $0.25 \%$ trypsin solution was used for cell passaging.

\section{Growth curves of HCT-8 and HCT-8/5-FU human colorectal cancer cell lines}

Single-cell suspensions at $5 \times 10^{4}$ cells/mL HCT- 8 and HCT-8/5-FU log-phase cells grown in RPMI-1640 medium were prepared. The cells were then seeded in 96-well plates (100 $\mu \mathrm{L} /$ well, $5 \times 10^{3}$ cells/well) and cultured for 1 to 7 days in replicates of 6 . CCK-8 kit was used to measure $\mathrm{OD}_{450}$. Time-dependent growth curves were plotted on the $X$-axis and $\mathrm{OD}$ on the $Y$-axis.

\section{CCK-8 detection of the cytotoxic effects of curcumin on HCT-8 and drug-resistant HCT-8/5-FU cells}

Single cell suspensions of HCT-8 and HCT-8/5-FU cells in log-phase growth were prepared in RPMI-1640 medium. Each well of a 96-well plate was seeded with $100 \mu \mathrm{L} /$ well $\left(10^{4}\right.$ cells $\left./ \mathrm{mL}\right)$ of the suspension, and the plate was incubated for $24 \mathrm{~h}$ at $37^{\circ} \mathrm{C}$ with $5 \% \mathrm{CO}_{2}$ to allow cell adhesion. Curcumin $(100 \mu \mathrm{L}$ of $0,2,4,8,10,12,16,20$, and $25 \mu \mathrm{g} / \mathrm{mL}$ curcumin concentrations) was added to the drug-sensitive and drug-resistant cultured cells, and the plates were incubated at $37^{\circ} \mathrm{C}$ for $48 \mathrm{~h}$. The culture medium was then aspirated and pre-made CCK- 8 solution was added. The plates were incubated for $2 \mathrm{~h}$ at $37^{\circ} \mathrm{C}$ after which $\mathrm{OD}_{450}$ was measured using a microplate reader. The rate of inhibition was calculated, and the concentration of curcumin $v$ s the rate of inhibition was plotted. Inhibition rate $(\%)=(1-$ experimental well A value / blank control well A value) x 100. The $\mathrm{IC}_{50}$ and non-cytotoxic $\mathrm{IC}_{10}$ of curcumin were calculated.

\section{CCK-8 detection of the cytotoxic effects of 5-FU on HCT-8 and drug-resistant HCT-8/5-FU cells}

HCT-8 and HCT-8/5-FU cells in log-phase growth were prepared in single-cell suspensions in RPMI-1640 medium and seeded into 96 -well plates $\left(100 \mu \mathrm{L} /\right.$ well at $10^{4}$ cells/ $\mathrm{mL}$ ), and the plates were then incubated for $24 \mathrm{~h}$ at $37^{\circ} \mathrm{C}$ with $5 \% \mathrm{CO}_{2}$ to allow cell adhesion. Cells were then treated with various concentrations of $5-\mathrm{FU}$ at $37^{\circ} \mathrm{C}$ for $48 \mathrm{~h}$. Drug-sensitive cells were treated with $0,0.05,0.1,0.2,0.4,0.8,3.2,6.4$, or $12.8 \mu \mathrm{g} / \mathrm{mL} 5$-FU; drug-resistant cells were treated with $0,30,60,90,150,300,600$, or $1000 \mu \mathrm{g} / \mathrm{mL} 5$-FU. After $48 \mathrm{~h}$, the culture medium was aspirated and CCK- 8 solution was added. The plates were incubated for $2 \mathrm{~h}$ at $37^{\circ} \mathrm{C} . \mathrm{OD}_{450}$ values were measured using a microplate reader and $\mathrm{IC}_{50}$ values were calculated. The resistance ratio was calculated as follows: resistance ratio $=\mathrm{IC}_{50}(\mathrm{HCT}-8 / 5-\mathrm{Fu})$ $/ \mathrm{IC}_{50}(\mathrm{HCT}-8)$. 
CCK-8 detection of the cytotoxic effects and reversal ratio of combined 5-FU/curcumin on drug-resistant HCT-8/5-FU cells

Single-cell suspensions of HCT-8/5-FU cells in log-phase growth were prepared in RPMI1640 medium and incubated in 96 -well plates $\left(100 \mu \mathrm{L} /\right.$ well at $10^{4}$ cells $\left./ \mathrm{mL}\right)$ for $24 \mathrm{~h}$ at $37^{\circ} \mathrm{C}$ with $5 \% \mathrm{CO}_{2}$ to allow cell adhesion. Different concentrations of 5-FU $(100 \mu \mathrm{L}$ of $0,30,60,90,150$, 300,600 , and $1000 \mu \mathrm{g} / \mathrm{mL}$ ) were then added, followed by the addition of different concentrations of curcumin $(0, \mathrm{X} 1$, and X2 $\mu \mathrm{g} / \mathrm{mL})$. After shaking gently, the plates were incubated for $48 \mathrm{~h}$ at $37^{\circ} \mathrm{C}$ with $5 \% \mathrm{CO}_{2}$ before the CCK- 8 detection. Each treatment was performed in replicates of 6. As determined in previous experiments, $\mathrm{X} 1$ and $\mathrm{X} 2$ were curcumin concentrations that inhibit $<10 \%$ growth of HCT- $8 / 5$-FU cells $\left(\mathrm{IC}_{10}\right)$. The $\mathrm{IC}_{50}$ of combined curcumin/5-FU on HCT-8/5-FU cells was calculated, and the reversal ratio $=\mathrm{IC}_{50}(\mathrm{HCT}-8 / 5-\mathrm{Fu}) / \mathrm{IC}_{50}(\mathrm{HCT}-8 / \mathrm{Fu}+$ curcumin $)$.

\section{Synergistic effect of combined curcumin/5-FU on drug-sensitive and drug-resistant HCT-8 cells}

Single-cell suspensions of HCT-8 and HCT-8/5-FU cells in log-phase growth were prepared in RPMI-1640 medium and incubated on 96 -well plates $\left(100 \mu \mathrm{L} /\right.$ well at $10^{3}$ cells/ $\mathrm{mL}$ ) for $24 \mathrm{~h}$ at $37^{\circ} \mathrm{C}$ with $5 \% \mathrm{CO}_{2}$ to allow cell adhesion. Cells were then treated with different concentrations of 5-FU and curcumin $(100 \mu \mathrm{L})$. Drug-sensitive HCT-8 cells were treated with 0.47 $\mu \mathrm{g} / \mathrm{mL} 5$-FU and $4.00,7.00$, and $10.50 \mu \mathrm{g} / \mathrm{mL}$ curcumin, respectively. Similarly, drug-resistant HCT-8/5-FU cells were treated with $96.40 \mu \mathrm{g} / \mathrm{mL} 5$-FU and $4.16,8.44$, and $12.96 \mu \mathrm{g} / \mathrm{mL}$ curcumin, respectively. Untreated controls were maintained for both drug-sensitive and drug-resistant cells, and each treatment for the two cell types had 6 replicates. After the cells were cultured for $48 \mathrm{~h}$ at $37^{\circ} \mathrm{C}$, the culture medium was aspirated and pre-made CCK-8 solution was added to each well. The plates were then incubated for $2 \mathrm{~h}$ at $37^{\circ} \mathrm{C}$. $\mathrm{OD}_{450}$ values for each well were measured using a microplate reader and the rate of inhibition of each treatment was calculated. The synergistic effect was calculated using the following formula: $\mathrm{q}=\mathrm{E}(\mathrm{AB}) /[\mathrm{EA}+(1-\mathrm{EA}) \times \mathrm{EB}]$, where $\mathrm{E}(\mathrm{AB})$ is the rate of inhibition of combined curcumin/5-FU, EA is the rate of inhibition of curcumin, and EB is the rate of inhibition of 5-FU. A value of $\mathrm{q}<0.85$ indicates that the two drugs are counteractive; when $\mathrm{q}=0.85-1.15$, the effect of the two drugs have an additive effect, and when $\mathrm{q}>1.15$, the two drugs have a synergistic effect. The greater the q value, the greater the synergistic effect.

\section{Effect of combined curcumin/5-FU on cell cycle and apoptosis of drug-resistant HCT-8/5-FU cells}

HCT-8/5-FU cells in log-phase growth were grown to $80 \%$ confluency and then treated with different concentrations of curcumin and 5-FU. Cells were cultured for $48 \mathrm{~h}$ at $37^{\circ} \mathrm{C}$ with $5 \% \mathrm{CO}_{2}$, and cell cycle and apoptosis were analyzed by flow cytometry. Data were analyzed by using the CellQuest software.

Quantitative real-time reverse transcription polymerase chain reaction (qRT-PCR) analysis of the effects of combined curcumin/5-FU on BCL-2, survivin, P-gp, and HSP-27 mRNA levels in drug-resistant HCT-8/5-FU cells

HCT- 8 and HCT-8/5-FU cells in the log-phase of growth were grown to $80 \%$ confluency

Genetics and Molecular Research 16 (2): gmr16029414 
and treated with different concentrations of curcumin and 5-FU. Cells were cultured for 48 $\mathrm{h}$ at $37^{\circ} \mathrm{C}$ with $5 \% \mathrm{CO}_{2}$, followed by qRT-PCR analysis. SYBR green dye was used to detect target gene expression, and GAPDH was used as the reference gene. Each reaction mixture contained $10 \mu \mathrm{L}$ PCR mix, $0.4 \mu \mathrm{L}$ primer $\mathrm{F}, 0.4 \mu \mathrm{L}$ primer $\mathrm{R}, 1.0 \mu \mathrm{L} \mathrm{cDNA}$, and $8.2 \mu \mathrm{LddH}_{2} \mathrm{O}$, with a total volume of $20 \mu \mathrm{L}$. PCR conditions were as follows: $50^{\circ} \mathrm{C}$ for $2 \mathrm{~min}, 95^{\circ} \mathrm{C}$ for 2 min pre-denaturation, $95^{\circ} \mathrm{C}$ for $15 \mathrm{~s}, 60^{\circ} \mathrm{C}$ for $60 \mathrm{~s}$ for 40 amplification cycles. The relative expression of the target gene was calculated using the formula: $2-\Delta \Delta \mathrm{Ct}=$ relative expression of target gene, $\Delta \mathrm{Ct}=\mathrm{Ct}($ target gene $)-\mathrm{Ct}(\mathrm{GAPDH}), \Delta \Delta \mathrm{Ct}=\Delta \mathrm{Ct}($ experimental sample $)$ $\Delta \mathrm{Ct}$ (control sample) (Table 1).

\begin{tabular}{|c|c|c|}
\hline Primer & Sequence & Product size (bp) \\
\hline BCL-2-F & GATAACGGAGGCTGGGATGC & \multirow[t]{2}{*}{150} \\
\hline BCL-2-R & TCACTTGTGGCCCAGATAGG & \\
\hline survivin-F(BIRC5) & GGACCACCGCATCTCTACAT & \multirow[t]{2}{*}{149} \\
\hline survivin-R(BIRC5) & CCAGCTCCTTGAAGCAGAAGAA & \\
\hline P-gp-F(ABCB1) & CGTGGGGCAAGTCAGTTCAT & \multirow[t]{2}{*}{139} \\
\hline P-gp-R(ABCB1) & TCCTTCCAATGTGTTCGGCA & \\
\hline HSP-27-F(HSPB1) & GGAGATCACCGGCAAGCAC & \multirow[t]{2}{*}{115} \\
\hline HSP-27-R(HSPB1) & GGAGGAGGAAACTTGGGTGG & \\
\hline GAPDH-F & TGTTGCCATCAATGACCCCTT & \multirow[t]{2}{*}{202} \\
\hline GAPDH-R & CTCCACGACGTACTCAGCG & \\
\hline
\end{tabular}

Western blot analysis of the effects of combined curcumin/5-FU on BCL-2, survivin, P-gp, and HSP-27 levels in drug-resistant HCT-8/5-FU cells

HCT-8/5-FU cells in log-phase growth were grown to $80 \%$ confluency and treated with different concentrations of curcumin and 5-FU. After culturing for $48 \mathrm{~h}$ at $37^{\circ} \mathrm{C}$ with $5 \% \mathrm{CO}_{2}$, the culture medium was aspirated followed by washing of the cells thrice with phosphate-buffered saline. Cell lysis buffer was added to the pellets and mixed with a pipette to ensure complete cell disruption. Total protein from cells that received each treatment was extracted and 5X sodium dodecyl sulfate-polyacrylamide gel electrophoresis loading buffer was added to the extracted protein, followed by heat denaturation. After cooling, samples were centrifuged $(8000 \mathrm{r} / \mathrm{min})$ for $5 \mathrm{~min}$, and the supernatants were collected. Proteins present in samples were separated by gel electrophoresis, which ran for $70 \mathrm{~min}$, followed by transferring of the gel onto a membrane at $100 \mathrm{~V}$. Membranes were blocked with 5\% nonfat milk for 1 $\mathrm{h}$, and then incubated overnight with primary antibody at $4{ }^{\circ} \mathrm{C}$. Incubation with secondary antibody was conducted for $1 \mathrm{~h}$ at $25^{\circ} \mathrm{C}$, followed by thorough washing of the membranes. Developer solutions A and B were mixed, and $1 \mathrm{~mL}$ mixture was added onto the membrane. ChemiScope Mini chemiluminescence imaging system was used to detect and photograph the target protein bands. $\beta$-Actin was used as the control.

\section{Statistical analysis}

SPSS 19.0 software was used to analyze the data. Multivariate comparison was performed using ANOVA. Equal group variances were analyzed by the least significant difference method and unequal group variances by the Dunnett's T3 method. The experimental data were expressed as means \pm standard error. Statistical significance was achieved when $\mathrm{P}<$ 0.05. Graphical data representation was generated by GraphPad Prism 5.0.

Genetics and Molecular Research 16 (2): gmr16029414 


\section{RESULTS}

\section{Cytotoxic effects of curcumin and 5-FU on HCT-8 and HCT-8/5-FU cells}

To test the cytotoxic effects of curcumin and 5-FU on HCT-8 and HCT-8/5-FU cells, the following analysis was undertaken. The $\mathrm{IC}_{50}$ of curcumin on HCT-8 and HCT-8/5-FU cells was $10.384 \mu \mathrm{g} / \mathrm{mL}$ and $12.962 \mu \mathrm{g} / \mathrm{mL}$, respectively (Figure 1A). The $\mathrm{IC}_{10}$ of curcumin on HCT8 and HCT-8/5-FU cells was $4.201 \mu \mathrm{g} / \mathrm{mL}$ and $5.241 \mu \mathrm{g} / \mathrm{mL}$, respectively. The $\mathrm{IC}_{50}$ of 5 -FU on HCT-8 and HCT-8/5-FU cells was $4.467 \mu \mathrm{g} / \mathrm{mL}$ and $331.095 \mu \mathrm{g} / \mathrm{mL}$, respectively, with a drug resistance ratio of 74.12 fold (Figures $1 \mathrm{~B}$ and C). When $4 \mu \mathrm{g} / \mathrm{mL}$ curcumin was added to various concentrations of $5-\mathrm{FU}$, the $\mathrm{IC}_{50}$ of this combined curcumin $/ 5-\mathrm{FU}$ was $179.257 \mu \mathrm{g} /$ $\mathrm{mL}$, representing a 1.85 -fold reversal. When curcumin was present at $5.5 \mu \mathrm{g} / \mathrm{mL}$, the $\mathrm{IC}_{50}$ of combined curcumin $/ 5$-FU was $89.246 \mu \mathrm{g} / \mathrm{mL}$, with a 3.71 -fold reversal. Since $4.0 \mu \mathrm{g} / \mathrm{mL}$ and $5.5 \mu \mathrm{g} / \mathrm{mL}$ curcumin result in a rate of inhibition of $<10 \%$ in HCT-8/5-FU cells, and the reversal ratio of $5.5 \mu \mathrm{g} / \mathrm{mL}$ curcumin was higher than that of $4.0 \mu \mathrm{g} / \mathrm{mL}$ curcumin, $5.5 \mu \mathrm{g} / \mathrm{mL}$ curcumin was used in subsequent experiments (Figure 1D).
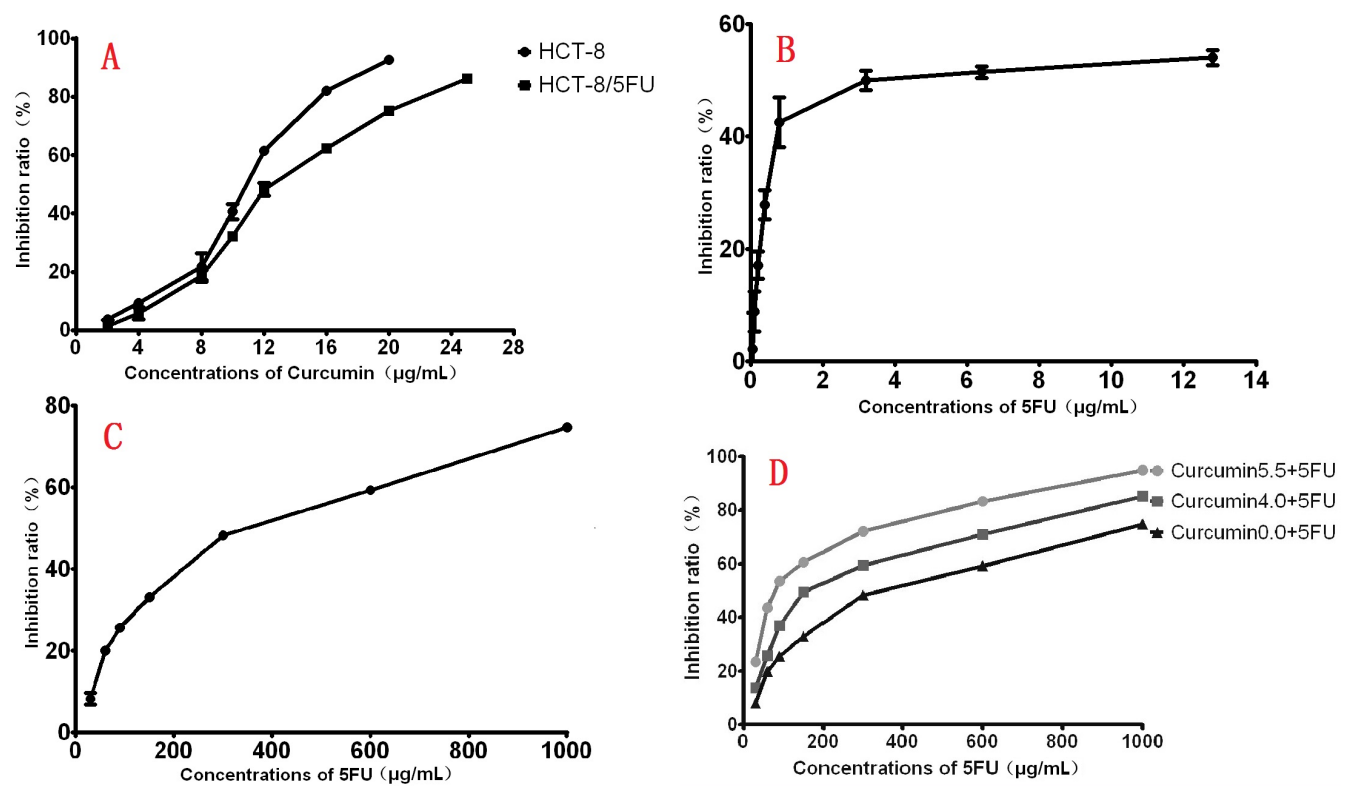

Figure 1. Cytotoxicity of curcumin and 5-FU on HCT-8 and HCT-8/5-FU cells. A. Inhibition curves of curcumin on HCT-8 and HCT-8/5-FU cells. B. Inhibition curves of 5-FU on HCT-8 cells. C. Inhibition curves of 5-FU on HCT-8/5-FU cells. D. Inhibition curves of curcumin + 5-FU or 5-FU on HCT-8/5-FU cells.

\section{Effect of combined curcumin/5-FU on cell cycle and apoptosis of HCT-8 and HCT- 8/5-FU cells}

To test effect of combined curcumin/5-FU on cell cycle and apoptosis of HCT-8 and HCT-8/5-FU cells, the following analysis was undertaken. When HCT-8 cells were treated with curcumin, 5-FU, or combined curcumin/5-FU, there was significant increase in the 
proportion of cells in the G0/G1 phase of the cell cycle, accompanied by a significant decrease in the proportion of cells in the $\mathrm{S}+\mathrm{G} 2 / \mathrm{M}$ cell cycle phase. Cells were arrested at the G0/ G1 phase and apoptosis was induced. The number of G0/G1 cells that received combined curcumin/5-FU was significantly higher than those that received either curcumin or 5-FU (P $<$ $0.05)$, suggesting that the combined use of curcumin and 5-FU induced HCT-8 cell apoptosis to a greater extent than that by 5-FU or curcumin alone (Table 2, Figure 2).

\section{Table 2. Effect of different treatments on HCT-8 and HCT-8/5-FU cell cycles (means $\pm \mathrm{s}, \mathrm{N}=12$ ).}

\begin{tabular}{l|l|c|c|c}
\hline Cell & Treatment & G0/G1 (\%) & S (\%) & G2/M (\%) \\
\hline \multirow{4}{*}{ HCT-8 } & Untreated & $36.87 \pm 1.29$ & $31.33 \pm 0.51$ & $31.80 \pm 1.74$ \\
\cline { 2 - 5 } & 5-FU & $61.37 \pm 0.90^{\Delta \#}$ & $21.73 \pm 4.27$ & $16.90 \pm 4.68$ \\
\cline { 2 - 5 } & Curcumin & $56.10 \pm 0.60^{\Delta \#}$ & $25.97 \pm 0.87^{\Delta}$ & $17.93 \pm 0.32^{\Delta}$ \\
\cline { 2 - 5 } & 5-FU + Curcumin & $71.77 \pm 1.52^{\Delta}$ & $15.17 \pm 4.50$ & $13.07 \pm 3.00^{\Delta}$ \\
\hline \multirow{2}{*}{ HCT-8/5-FU } & Untreated & $36.53 \pm 1.07$ & $33.70 \pm 2.88$ & $29.77 \pm 1.86$ \\
\cline { 2 - 5 } & 5-FU & $61.76 \pm 0.06^{\Delta}$ & $17.27 \pm 1.63^{\Delta}$ & $19.97 \pm 1.57^{\Delta}$ \\
\cline { 2 - 5 } & Curcumin & $61.40 \pm 1.31^{\Delta}$ & $19.43 \pm 3.25^{\Delta}$ & $13.43 \pm 0.32^{\Delta}$ \\
\cline { 2 - 5 } & 5-FU + Curcumin & $73.93 \pm 0.93^{\Delta}$ & $12.63 \pm 0.90^{\Delta}$ & $13.43 \pm 0.37$ \\
\hline
\end{tabular}

${ }^{\Delta} \mathrm{P}<0.05$ when compared with untreated cells. ${ }^{\#} \mathrm{P}<0.05$ when compared with cells treated with 5 -FU + curcumin.

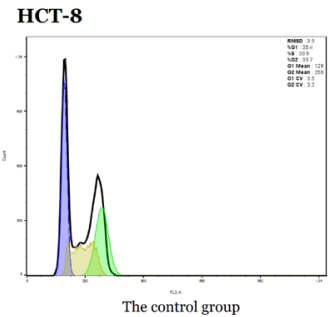

The control group

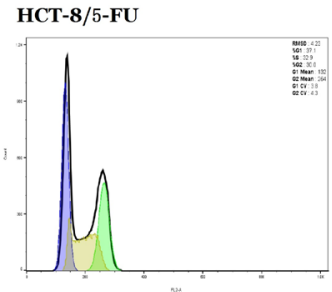

The control group

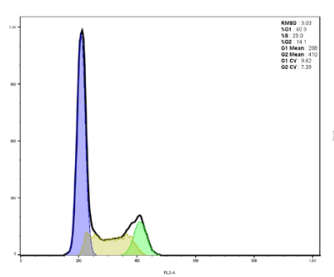

The 5-FU group

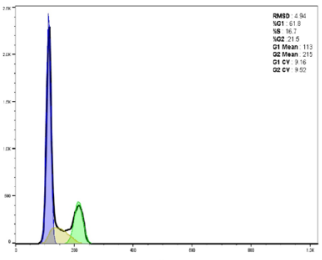

The 5-FU group

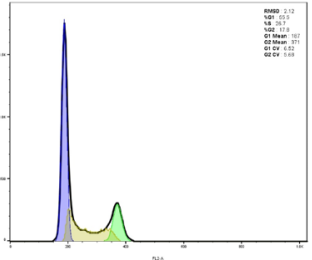

The curcumin group

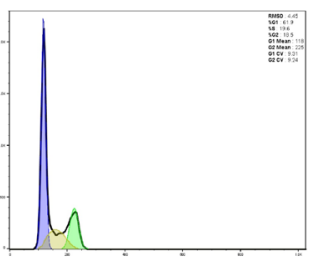

The curcumin group

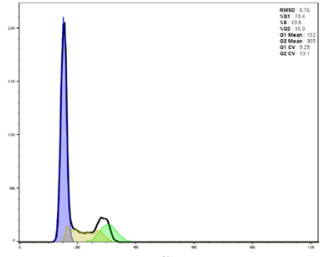

The 5-FU + curcumin group

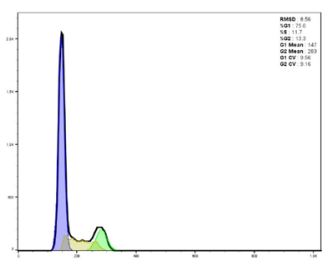

The 5-FU + curcumin group

Figure 2. Effect of different treatments on HCT- 8 and HCT-8/5-FU cell cycles.

HCT-8/5-FU cells treated with combined curcumin/5-FU increased in proportion in G0/G1 phase with a significant decrease in the number of S-phase cells. The cell cycle was arrested at G0/G1 phase and apoptosis was induced. The number of G0/G1 cells in the combined curcumin/5-FU group was significantly higher than that in the curcumin or 5-FU groups $(\mathrm{P}<0.05)$, suggesting that the combined use of curcumin and $5-\mathrm{FU}$ induces greater HCT-8/5-FU cell apoptosis than the use of either 5-FU or curcumin alone (Table 2, Figure 2).

When HCT-8 or HCT-8/5-FU cells were treated with curcumin, 5-FU, or combined curcumin/5-FU, apoptosis in all the treated groups of cells was significantly elevated compared to that in the untreated cells $(\mathrm{P}<0.05)$. In addition, apoptosis in the combined curcumin $/ 5$ $\mathrm{Fu}$ group was significantly higher than that in the curcumin-alone or 5 -FU-alone groups $(\mathrm{P}<$ 0.05) (Table 3, Figure 3). 
Table 3. Effect of different treatments on HCT-8 and HCT-8/5-FU cell apoptosis (means $\pm \mathrm{s}, \mathrm{N}=12$ ).

\begin{tabular}{l|c|c}
\hline Treatment group & HCT-8 apoptosis (\%) & HCT-8/5-FU apoptosis (\%) \\
\hline Untreated & $2.90 \pm 0.56$ & $3.50 \pm 1.22$ \\
\hline 5 -FU & $18.50 \pm 0.82^{\Delta \sharp}$ & $18.40 \pm 1.61^{\Delta \sharp}$ \\
\hline Curcumin & $36.63 \pm 2.10^{\Delta \sharp}$ & $41.80 \pm 2.72^{\Delta \sharp}$ \\
\hline 5-FU + Curcumin & $65.80 \pm 0.89^{\Delta}$ & $79.60 \pm 3.96^{\Delta}$ \\
\hline
\end{tabular}

${ }^{\Delta} \mathrm{P}<0.05$ when compared with untreated cells. ${ }^{\#} \mathrm{P}<0.05$ when compared with cells treated with 5 -FU + curcumin.

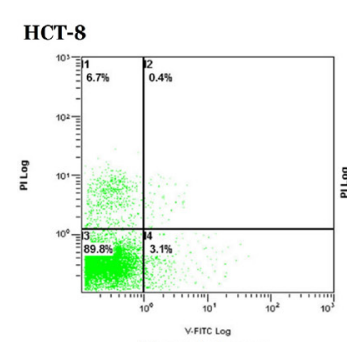

The control group

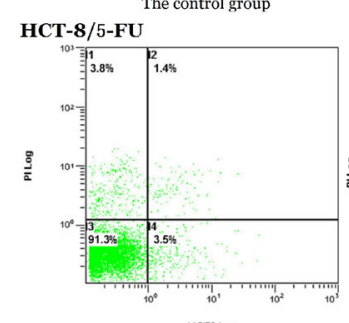

The control group

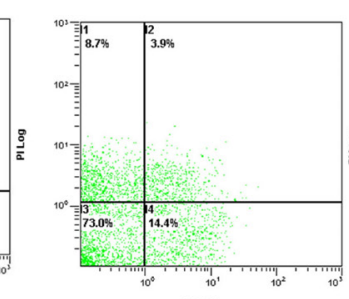

The 5 -FU group

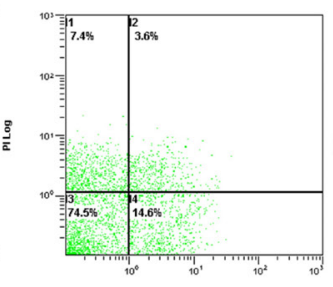

The 5 -FU group

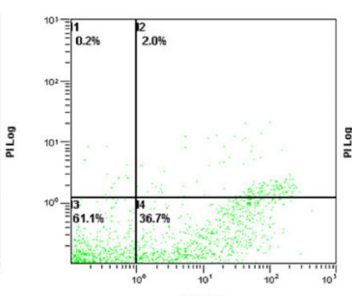

The curcumin group

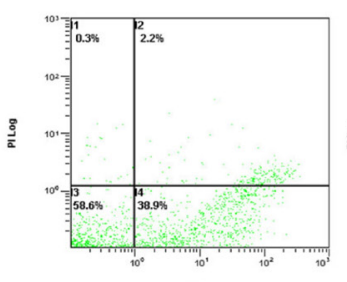

The curcumin group

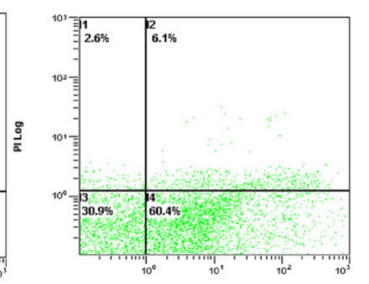

The 5 -FU + r.frc log curcumin group

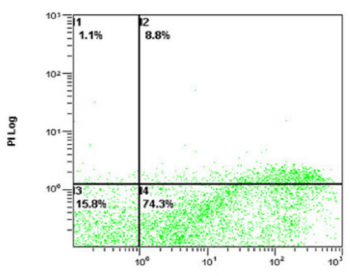

The 5 -FU + crirc log

Figure 3. Effect of different treatments on HCT-8 and HCT-8/5-FU cell apoptosis.

\section{BCL-2, survivin, P-gp, and HSP-27 mRNA expression after treatments}

To test the effect of combined curcumin/5-FU on cell cycle and apoptosis of HCT-8 and HCT-8/5-FU cells, the qRT-PCR method was used. Levels of BCL-2, survivin, P-gp, and HSP-27 mRNA are markedly different in HCT-8 or HCT-8/5-FU cells treated with curcumin, 5-FU, or combined curcumin/5-FU than those observed in untreated cells $(\mathrm{P}<$ 0.05). Furthermore, combined curcumin/5-FU treatment resulted in significantly lower levels of mRNA for these markers compared to those observed in the curcumin- or 5-FU-treated cells $(\mathrm{P}<0.05)$. There were no significant differences in the expression levels of these genes between cells treated with curcumin alone or 5-FU-alone $(\mathrm{P}>0.05)$ (Table 4$)$.

\section{Western blot analysis of BCL-2, survivin, P-gp, and HSP-27 levels after the treatments}

Early qRT-PCR analysis determined that mRNA levels of BCL-2, survivin, P-gp, and HSP-27 were not significantly different between cells treated with curcumin and those treated with 5-FU. Therefore, subsequent western blot analyses did not include cells treated only with 5-FU.

To test levels of BCL-2, survivin, P-gp, and HSP-27 in cells treated with combined HCT-8/5-FU, the western blot method were used. Protein levels were quantified by density analysis of HCT-8/5-FU cells that received the different treatments. The results indicated that 
untreated HCT-8/5-FU cells had relatively high levels of BCL-2, survivin, P-gp, and HSP-27. Drug treatment reduced the protein levels by various degrees. In the 5-FU + curcumin cells, levels of BCL-2, survivin, P-gp, and HSP-27 were significantly different than those in the untreated control cells $(\mathrm{P}<0.05)$. Curcumin-only treatment resulted in significant changes in BCL-2, P-gp, and HSP-27 levels ( $\mathrm{P}<0.05)$, but not in survivin levels, when compared to those in the untreated cells. Of all the measured proteins, only the expression of HSP-27 was significantly different between the 5-FU + curcumin and curcumin-only treated cells $(\mathrm{P}<$ 0.05) (Table 5 and Figure 4).

Table 4. Relative quantitation of mRNA levels in HCT-8 and HCT-8/5-FU cells after different treatments (means $\pm \mathrm{s}, \mathrm{N}=12$ ).

\begin{tabular}{l|l|c|c|c|c}
\hline Cell & Treatment & BCL2 & Survivin & P-gp & HSP-27 \\
\hline \multirow{4}{*}{ HCT-8 } & Untreated & $1.002 \pm 0.079$ & $1.003 \pm 0.092$ & $1.003 \pm 0.102$ & $1.014 \pm 0.204$ \\
\cline { 2 - 6 } & 5-FU & $0.454 \pm 0.065^{\Delta}$ & $0.428 \pm 0.032^{\Delta}$ & $0.326 \pm 0.056^{\Delta}$ & $0.405 \pm 0.054^{\Delta}$ \\
\cline { 2 - 6 } & Curcumin & $0.453 \pm 0.099^{\Delta}$ & $0.494 \pm 0.045^{\Delta}$ & $0.343 \pm 0.038^{\Delta}$ & $0.334 \pm 0.127^{\Delta}$ \\
\cline { 2 - 6 } & 5-FU+Curcumin & $0.315 \pm 0.062^{\Delta}$ & $0.387 \pm 0.067^{\Delta}$ & $0.189 \pm 0.043^{\Delta \Lambda}$ & $0.264 \pm 0.024^{\Delta}$ \\
\hline \multirow{3}{*}{ HCT-8/5-FU } & Untreated & $1.012 \pm 0.191$ & $1.013 \pm 0.199$ & $1.004 \pm 0.105$ & $1.003 \pm 0.094$ \\
\cline { 2 - 6 } & 5-FU & $0.323 \pm 0.062^{\Delta *}$ & $0.374 \pm 0.067^{\Delta *}$ & $0.478 \pm 0.074^{\Delta \# *}$ & $0.566 \pm 0.100^{\Delta \# *}$ \\
\cline { 2 - 6 } & Curcumin & $0.394 \pm 0.067^{\Delta}$ & $0.387 \pm 0.041^{\Delta}$ & $0.406 \pm 0.066^{\Delta *}$ & $0.463 \pm 0.100^{\Delta \#}$ \\
\cline { 2 - 6 } & 5-FU+ Curcumin & $0.235 \pm 0.035^{\Delta}$ & $0.297 \pm 0.016^{\Delta}$ & $0.275 \pm 0.018^{\Delta}$ & $0.281 \pm 0.094^{\Delta}$ \\
\hline
\end{tabular}

${ }^{\Delta} \mathrm{P}<0.05$ when compared with untreated cells. ${ }^{\Delta} \mathrm{P}<0.05$ when compared with HCT-8 cells treated with 5 -FU. ${ }^{\#} \mathrm{P}<$ 0.05 when compared with HCT-8/5-FU cells treated with $5-\mathrm{FU}+$ curcumin. $* \mathrm{P}>0.05$ when compared with HCT8/5-FU cells treated with curcumin.

Table 5. Relative quantitation of protein expression in HCT-8/5-FU cells after different treatments (means $\pm \mathrm{s}$, $\mathrm{N}=9$ ).

\begin{tabular}{l|c|c|c|c}
\hline Treatment & BCL-2 & Survivin & P-gp & HSP-27 \\
\hline Untreated & $0.709 \pm 0.054$ & $0.588 \pm 0.052$ & $0.560 \pm 0.027$ & $0.652 \pm 0.082$ \\
\hline Curcumin & $0.442 \pm 0.013^{\Delta}$ & $0.434 \pm 0.012$ & $0.391 \pm 0.043^{\Delta}$ & $0.408 \pm 0.191^{\Delta}$ \\
\hline 5-FU + Curcumin & $0.457 \pm 0.037^{\Delta}$ & $0.399 \pm 0.139^{\Delta}$ & $0.275 \pm 0.104^{\Delta}$ & $0.088 \pm 0.025^{\Delta}$ \\
\hline
\end{tabular}

${ }^{\Delta} \mathrm{P}<0.05$ when compared with untreated cells. ${ }^{\Delta} \mathrm{P}<0.05$ when compared with curcumin cells.

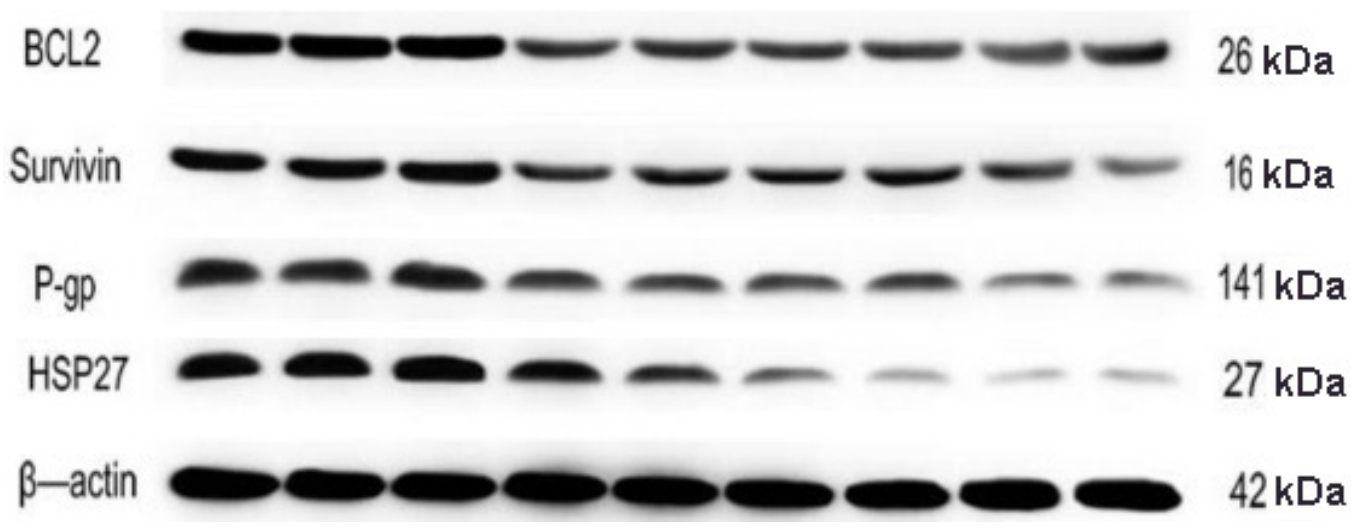

Figure 4. Differences in levels of BCL-2, survivin, P-gp, and HSP-27 in HCT-8/5-FU cells that received the different treatments. Note From left to right: bands 1, 2, and 3 are from untreated control cells; bands 4, 5, and 6 are from curcumin-treated cells; bands 7, 8, and 9 are from 5-FU + curcumin-treated cells. 


\section{DISCUSSION}

Chemotherapy is one of the critical strategies used in the treatment of cancer. However, its clinical efficacy is often far from satisfactory because of the property of MDR in tumor cells. The mechanism of MDR is very complex and involves many factors and the following pathways: 1) high expression of proteins that confer drug-resistance, such as MRP and P-gp; 2) abnormal activity of drug metabolism-related enzymes, including glutathione transferase and DNA topoisomerase; 3) aberrations in the apoptosis pathway; 4) and the presence of hypoxia and a low-glucose microenvironment. Understanding the mechanism of multidrug resistance in colorectal cancer and improving therapeutic efficacy are issues that require immediate attention. Many resistance-reversing drugs such as cyclosporin A, verapamil, quinidine, trifluoperazine, and tamoxifen have limited clinical applications because of their high toxicity or low activity. It is, therefore, extremely important to search for and identify reversal agents with high efficacy and low toxicity. Recent studies have shown that curcumin can reduce MDR by regulating the expression of genes involved in drug resistance and apoptosis in cancer cells (Negi et al., 2014; Baldwin et al., 2015; Wang et al., 2016a).

$B C L-2$ belongs to a family of well-studied anti-apoptosis genes that encode membrane-bound proteins involved in cell survival. BCL-2 inhibits the production of reactive oxygen species (ROS), regulate intracellular $\mathrm{Ca}^{2+}$ concentrations, modulate transmembrane transportation, bind to signal transduction proteins, and regulate signaling pathways, all of which are associated with the development of MDR (El-Khattouti et al., 2013; Hoshyar et al., 2013; Cerezo et al., 2015).

Survivin is another anti-apoptosis gene that promotes cell proliferation and inhibits apoptosis. Although expressed at low levels in normal adult thymus and testis, survivin is highly upregulated in solid malignant tumors. There are a number of molecular mechanisms by which survivin inhibits apoptosis. Firstly, it has the ability to inhibit caspases directly, predominantly caspase- 3 and caspase-7, to block apoptosis. Survivin can also inhibit caspases indirectly through $\mathrm{p} 21$ by interacting with cyclin-dependent kinase CDK-4 to form a survivinCDK4 complex, which then releases p21 from the complex. p21, in turn, binds to the mitochondrial caspase 3 to inhibit caspase activity and prevent apoptosis. Secondly, survivin can also inhibit the NF-kb signaling pathway to indirectly achieve an anti-apoptotic effect (Wu et al., 2015; Gao et al., 2016). Furthermore, clinical studies have revealed that survivin levels are closely associated with the onset, progression, and prognosis of gastric cancer (Han et al., 2015; Pandey et al., 2015; Wang et al., 2016b; Yang et al., 2016). In the present study, high levels of BCL-2 and survivin were found in untreated HCT-8/5-FU cells. Curcumin or combined curcumin/5-FU treatment resulted in a marked and statistically significant decrease in BCL-2 and survivin levels. The decrease in BCL-2 and survivin levels was consistent with the curcumin-induced apoptosis seen in our earlier experiments. Reduction in BCL-2 levels resulting in upregulation of Bax and Caspase-3, elevation of the Bax/BCL-2 ratio, and increased activation of Caspase-3 may be one possible underlying mechanism for apoptosis. In addition, reduced survivin levels could also lead to decreased inhibition of Caspase-3, thereby promoting apoptosis.

P-gp is a transmembrane glycoprotein, encoded by the multidrug resistance gene, and functions as an energy-dependent efflux pump in drug-resistant cells. P-gp levels are associated with cell membrane permeability, intracellular drug concentration, and drug binding capacity. P-gp may play a role in the reversal of drug resistance by promoting apoptosis-inhibiting

Genetics and Molecular Research 16 (2): gmr16029414 
protein expression and inhibiting enzyme activity (Chhikara et al., 2015; Han et al., 2005). In the present study, the elevated P-gp expression detected in untreated HCT-8/5-FU control cells was consistent with that observed in a typical drug-resistant cell line. Curcumin and 5FU + curcumin interventions resulted in a significant decrease in P-gp expression, and its ability to reverse drug resistance may be achieved through the upregulation of ATP-dependent Topo-II.

HSP-27 is a small protein, belonging to the HSP family in human cells, and a relatively newly identified regulator of 5-FU resistance in colorectal cancer (Schweiger et al., 2015). Its functions include protecting cells from stress-induced damage and acting as a chaperone in the maintenance of intracellular protein activity. HSP-27 plays a role in the regulation of cell proliferation and differentiation, as well as apoptosis signal transduction (Ghosh et al., 2013). Increased HSP-27 expression could reduce the ability of chemotherapy to destroy tumor cells, suggesting that HSP-27 can influence the resistance to chemotherapy (Hsu et al., 2011; Hayashi et al., 2012; Zhao et al., 2012). The importance of HSP-27 in drug resistance has been further demonstrated in studies where inhibition of HSP-27 expression by siRNA increased the sensitivity of cancer cell lines to chemotherapeutic drugs (Lelj-Garolla et al., 2015). In the present study, HSP-27 expression in curcumin- or curcumin/5-FU-treated cells was significantly lower than that in untreated control cells. This finding suggested that curcumin was able to reverse drug resistance via inhibition of HSP-27 expression and enhancement of sensitivity to chemotherapeutic drugs. The underlying mechanism for this reversal may be associated with HSP-27-induced AKT phosphorylation in the NF-kB pathway, which in turn inhibits p21 nuclear translocation.

Recent studies on the reversal of multidrug resistance by curcumin have focused on gastric, liver, and cervical cancers. There have also been a few on the reversal of multidrug resistance by curcumin in colorectal cancer cell lines. However, to our best knowledge, no study on the reversal of multidrug resistance has focused on the colorectal cancer cell line HCT8/5-FU. In the present study, we have examined the resistance-reversal effect of curcumin on the drug-resistant human colorectal cancer cell line HCT-8/5-FU. We observed that curcumin treatment resulted in significantly decreased levels of expression of BCL-2, survivin, P-gp, and HSP-27 compared to those in untreated control cells, demonstrating the ability of curcumin to reverse drug resistance in the human colorectal cancer cell line HCT-8/5-FU. This reversal could be due to the reduction in P-gp and HSP-27 expression levels, thereby reducing drug efflux from tumor cells and increasing intracellular drug concentrations. In addition, downregulated expression of BCL-2 and survivin could inhibit tumor cell proliferation and enhance apoptosis. Curcumin may therefore have clinical implications as a new therapeutic agent for colorectal cancer. Since the resistance-reversal property of curcumin was examined only on the HCT-8/5-FU cell line, we will assess this property of curcumin using other human colorectal cancer cell lines in the future.

\section{Conflicts of interest}

The authors declare no conflict of interest.

\section{ACKNOWLEDGMENTS}

Research supported by grant (\#Y-L2014-002) from the CSCO-Lizon Cancer research foundation of traditional Chinese medicine.

Genetics and Molecular Research 16 (2): gmr16029414 


\section{REFERENCES}

Ahmad N, Khan AH, Syed Sulaiman SA and Javaid A (2015). Fluoroquinolones resistance in multidrug-resistant tuberculosis in Pakistan and suitability of guidelines recommended standardized regimen. Int. J. Mycobacteriol. 4: 258-259. https://doi.org/10.1016/j.ijmyco.2015.05.012

Baldwin PR, Reeves AZ, Powell KR, Napier RJ, et al. (2015). Monocarbonyl analogs of curcumin inhibit growth of antibiotic sensitive and resistant strains of Mycobacterium tuberculosis. Eur. J. Med. Chem. 92: 693-699. https://doi. org/10.1016/j.ejmech.2015.01.020

Cerezo D, Cánovas M, García-Peñarrubia P and Martín-Orozco E (2015). Collateral sensitivity to cold stress and differential BCL-2 family expression in new daunomycin-resistant lymphoblastoid cell lines. Exp. Cell Res. 331: 11-20. https://doi.org/10.1016/.j.yexcr.2014.11.017

Chang HY, Pan KL, Ma FC, Jiao XY, et al. (2006). The study on reversing mechanism of multidrug resistance of K562/ A02 cell line by curcumin and erythromycin. Zhonghua Xue Ye Xue Za Zhi 27: 254-258.

Chhikara S, Sazawal S, Mishra P, Chaubey R, et al. (2015). C1236T polymorphism in MDR1 gene correlates with therapeutic response to imatinib mesylate in Indian patients with chronic myeloid leukaemia. Natl. Med. J. India 28: $272-275$.

Colacino JA, McDermott SP, Sartor MA, Wicha MS, et al. (2016). Transcriptomic profiling of curcumin-treated human breast stem cells identifies a role for stearoyl-coa desaturase in breast cancer prevention. Breast Cancer Res. Treat. 158: 29-41. https://doi.org/10.1007/s10549-016-3854-4

El-Khattouti A, Selimovic D, Haikel Y and Hassan M (2013). Crosstalk between apoptosis and autophagy: molecular mechanisms and therapeutic strategies in cancer. J. Cell Death 6: 37-55.

Gao DQ, Qian S and Ju T (2016). Anticancer activity of Honokiol against lymphoid malignant cells via activation of ROSJNK and attenuation of Nrf2 and NF-кB. J. BUON 21: 673-679.

Ghosh A, Lai C, McDonald S, Suraweera N, et al. (2013). HSP27 expression in primary colorectal cancers is dependent on mutation of KRAS and PI3K/AKT activation status and is independent of TP53. Exp. Mol. Pathol. 94: 103-108. https://doi.org/10.1016/j.yexmp.2012.09.001

Guzzarlamudi S, Singh PK, Pawar VK, Singh Y, et al. (2016). Synergistic chemotherapeutic activity of curcumin bearing methoxypolyethylene glycol-g-linoleic acid based micelles on breast cancer cells. J. Nanosci. Nanotechnol. 16: 4180-4190. https://doi.org/10.1166/jnn.2016.11699

Han G, Gong H, Wang Y, Guo S, et al. (2015). AMPK/mTOR-mediated inhibition of survivin partly contributes to metformin-induced apoptosis in human gastric cancer cell. Cancer Biol. Ther. 16: 77-87. https://doi.org/10.4161/15 $\underline{384047.2014 .987021}$

Han Y, Bu LM, Ji X, Liu CY, et al. (2005). Modulation of multidrug resistance by andrographolid in a HCT-8/5-FU multidrug-resistant colorectal cancer cell line. Chin. J. Dig. Dis. 6: 82-86. https://doi.org/10.1111/j.14439573.2005.00197.x

Hayashi N, Peacock JW, Beraldi E, Zoubeidi A, et al. (2012). Hsp27 silencing coordinately inhibits proliferation and promotes Fas-induced apoptosis by regulating the PEA-15 molecular switch. Cell Death Differ. 19: 990-1002. https:// doi.org/10.1038/cdd.2011.184

Hoshyar R, Bathaie SZ and Sadeghizadeh M (2013). Crocin triggers the apoptosis through increasing the Bax/Bcl-2 ratio and caspase activation in human gastric adenocarcinoma, AGS, cells. DNA Cell Biol. 32: 50-57. https://doi. org/10.1089/dna.2012.1866

Hsu HS, Lin JH, Huang WC, Hsu TW, et al. (2011). Chemoresistance of lung cancer stemlike cells depends on activation of Hsp27. Cancer 117: 1516-1528. https://doi.org/10.1002/cncr.25599

Lelj-Garolla B, Kumano M, Beraldi E, Nappi L, et al. (2015). Hsp27 inhibition with OGX-427 sensitizes non-small cell lung cancer cells to erlotinib and chemotherapy. Mol. Cancer Ther. 14: 1107-1116. https://doi.org/10.1158/15357163.MCT-14-0866

Li H and Li L (2015). Relationship of GSTP1 lower expression and multidrug resistance reversing of curcumin on human colon carcinoma cells. Zhonghua Yi Xue Za Zhi 95: 2478-2482.

Lu WD, Qin Y, Yang C, Li L, et al. (2013). Effect of curcumin on human colon cancer multidrug resistance in vitro and in vivo. Clinics (Sao Paulo) 68: 694-701. https://doi.org/10.6061/clinics/2013(05)18

Muddineti OS, Kumari P, Ajjarapu S, Lakhani PM, et al. (2016). Xanthan gum stabilized PEGylated gold nanoparticles for improved delivery of curcumin in cancer. Nanotechnology 27: 325101. https://doi.org/10.1088/0957$\underline{4484 / 27 / 32 / 325101}$

Negi N, Prakash P, Gupta ML and Mohapatra TM (2014). Possible role of curcumin as an efflux pump inhibitor in multi drug resistant clinical isolates of Pseudomonas aeruginosa. J. Clin. Diagn. Res. 8: DC04-DC07.

Genetics and Molecular Research 16 (2): gmr16029414 
Pandey A, Vishnoi K, Mahata S, Tripathi SC, et al. (2015). Berberine and curcumin target survivin and STAT3 in gastric cancer cells and synergize actions of standard chemotherapeutic 5-fluorouracil. Nutr. Cancer 67: 1293-1304. https:// doi.org/10.1080/01635581.2015.1085581

Schweiger T, Nikolowsky C, Starlinger P, Traxler D, et al. (2015). Stromal expression of heat-shock protein 27 is associated with worse clinical outcome in patients with colorectal cancer lung metastases. PLoS One 10: e0120724. https://doi. org/10.1371/journal.pone.0120724

Wang J, Wang F, Li F, Zhang W, et al. (2016a). A multifunctional poly(curcumin) nanomedicine for dual-modal targeted delivery, intracellular responsive release, dual-drug treatment and imaging of multidrug resistant cancer cells. $J$. Mater. Chem. B Mater. Biol. Med. 4: 2954-2962. https://doi.org/10.1039/C5TB02450A

Wang TA, Zhang XD, Guo XY, Xian SL, et al. (2016b). 3-bromopyruvate and sodium citrate target glycolysis, suppress survivin, and induce mitochondrial-mediated apoptosis in gastric cancer cells and inhibit gastric orthotopic transplantation tumor growth. Oncol. Rep. 35: 1287-1296.

Wu M, Chen J, Wang Y, Hu J, et al. (2015). URGCP/URG4 promotes apoptotic resistance in bladder cancer cells by activating NF- $\mathrm{KB}$ signaling. Oncotarget 6: 30887-30901.

Yang B, Huang J, Liu H, Guo W, et al. (2016). miR-335 directly, while miR-34a indirectly modulate survivin expression and regulate growth, apoptosis, and invasion of gastric cancer cells. Tumour Biol. 37: 1771-1779. https://doi. org/10.1007/s13277-015-3951-8

Zhao M, Shen F, Yin YX, Yang YY, et al. (2012). Increased expression of heat shock protein 27 correlates with peritoneal metastasis in epithelial ovarian cancer. Reprod. Sci. 19: 748-753. https://doi.org/10.1177/1933719111432875

Genetics and Molecular Research 16 (2): gmr16029414 